\title{
Ravitsemisoskus kui pärimusrühma ühisteadmus: Siberi Rõžkovo küla näide
}

\begin{abstract}
Anu Korb
Teesid: Artiklis jälgitakse rahvapäraste ravimisviiside-võtete kasutamist Lääne-Siberi luteriusuliste segaasundusena 1803. aasta paiku asutatud Rõžkovo küla virulaste (st eestlaste ja soomlaste) pärimusrühmas. Materjal põhineb autori välitöödel aastatest 1999,2000 ja 2004 . Paljurahvuseliseks ja -keelseks külaks muutunud paigas on tänapäevalgi lätlastel ja virulastel kummalgi oma territoorium - läti ja viru pool.

Rahvaarstid virulaste pärimusrühmas eriliselt esile ei tõuse, sest ravitsemisoskusse suhtutakse kui põlvest põlve edasi antud kogukonna pärimuslikku teadmisse. Need oskused ja ravisõnad arvatakse olevat igaühele kättesaadavad ja õpitavad. Mitmekultuuriline ja -keelne keskkond on traditsiooni vaid rikastanud, rahvapäraste ravimisviiside-võtete püsimisele on kaasa aidanud ka tegelik praktiline vajadus. Traditsiooni taandumist on soodustanud nii pikaaegne ühiskondlik-poliitiline surve rahvaravitsejatele, riikliku meditsiinisüsteemi jõuline arendamine kui ka pärimusrühma liikmete endi suhtumine, kes aktsepteerisid eeskätt soliidses eas ravitsejaid. Muutused on toimunud ravivõtete mugandamise, loitsutüüpide ja tekstivaliku ahenemise suunas. Samas võib tänapäeva suurema poliitilise ja majandusliku vabaduse tingimustes täheldada üha kasvavat huvi rahvapäraste raviviiside ja -võtete vastu.
\end{abstract}

Märksõnad: kogukond, mitmekultuurilisus, rahvameditsiin, raviloits, ravitseja, Siber

\section{Sissejuhatus}

Alates oma esimesest Siberi kogumismatkast aastal 1991 Ida-Siberi Minussinski piirkonna eesti küladesse Ülem-Suetukki ja Ülem-Bulankasse sain jälgida rahvapäraste ravitsemisvõtete-oskuste praktilist kasutamist pärimusrühmas. Välitöid Siberi eesti kogukondades jätkates tõdesin, et vanemates (asutatud 150-200 aastat tagasi) Siberi eestlaste ja/või luteriusuliste külades (Ülem-Suetuk, Ülem-Bulanka, Rõžkovo), aga osalt ka hilisemates sadakond aastat tagasi asutatutes (nt Tomski oblasti Kaseküla, Omski oblasti Lillikülä) on ravitsemisoskus tänapäevalgi kogukonna ühine pärimuslik tead- 
mus, mitte vaid üksikute pärisosa. Olukord erines suuresti samal perioodil Eestimaa eri piirkondadest kogutust, kus rahvapäraste ravimisviiside-võtete, eriti aga sõnamaagia kasutamine polnud samavõrd tuntud.

Artiklis jälgin rahvapäraste ravimisviiside-võtete kasutamist ja ravitseja staatust Siberi Rõžkovo küla virulaste (st eestlaste ja soomlaste) pärimusrühmas. Materjal põhineb 1999., 2000. ja 2004. aasta välitöödel, kus küsitlesin eelkõige vanema põlvkonna esindajaid (sündinud aastatel 1913-1933), kes oskasid eesti keelt, kuid ka üksikuid pärast Teist maailmasõda sündinuid. Võrdlusmaterjalina kasutan teistest Siberi eesti kogukondadest ja Eestimaalt talletatud rahvameditsiini ja ravitsejatesse puutuvat ainest.

\section{Rõžkovo küla ja virulaste kogukonna taustast ja keelesituatsioonist}

Rõžkovo on Lääne-Siberi (tänapäeval Omski oblasti Krutinka rajoon) vanim luteriusuliste segaasundus, mis on asutatud 1803. aasta paiku Vene tsaarivalitsuse poolt välja saadetuist ja saanud täiendust hilisemaist väljarännanuist. Sinna paigutati eeskätt luteriusulisi: eestlasi, lätlasi, sakslasi, rootslasi, soomlasi, aga ka ingerisoomlasi ja õigeusklikke venelasi. 20. sajandi lõpuks oli Rõžkovost saanud paljurahvuseline ja -keelne küla. Külanõukogu andmetel aastast 1997 elas seal 11 rahva esindajaid, umbes 750 inimest. Enamusrahvuseks olid saanud venelased (u 400), kelle osa kasvas oluliselt pärast Teist maailmasõda eri paigust juurdetulijate arvelt. Seega ei ole nende puhul põhjust rääkida ühtsest vene kogukonnast. Elanike arvult teisel-kolmandal kohal olid lätlased ( $u$ 145) ja eestlased (u 115), kummalgi on tänapäevani külas oma territoorium - läti ja viru pool. Külas algselt elanud luteriusulistest olid külanõukogu statistikas esindatud veel sakslased (u 20), aga mitte soomlased-rootslased. Külaelanikud seda statistikat täpseks ei pidanud ning arvasid külas elavat ligi paarikümne rahva esindajaid, sealhulgas ka soomlasi. Omi asunduse soomlaste andmetel olnud Venemaa soomlastel ja ingerisoomlastel pärast Teist maailmasõda ja Talvesõda ohtlik end soomlasena määratleda. Soome nimi muudetud sageli venepäraseks ning rahvuseks märgitud eestlane (SKSÄ 155; 1991). Siirdlaste identiteedivahetust või kaksikidentiteeti tuleb asukohamaa poliitilise või majandusliku surve tõttu maailmapraktikas ette võrdlemisi sageli, vt nt Norra kveenid (Sulkala 2002: 217). Siberi soomlased on sealsele eestlaskonnale lisa andnud. Ajapikku on keelelt ja kultuurilt lähedased eestlased ja soomlased saanud Rõžkovos ühisnimetuse virulased, mujal Siberis ingerlaste ja soomlaste naabruses on aga virulane eestlase enesenimetus. 


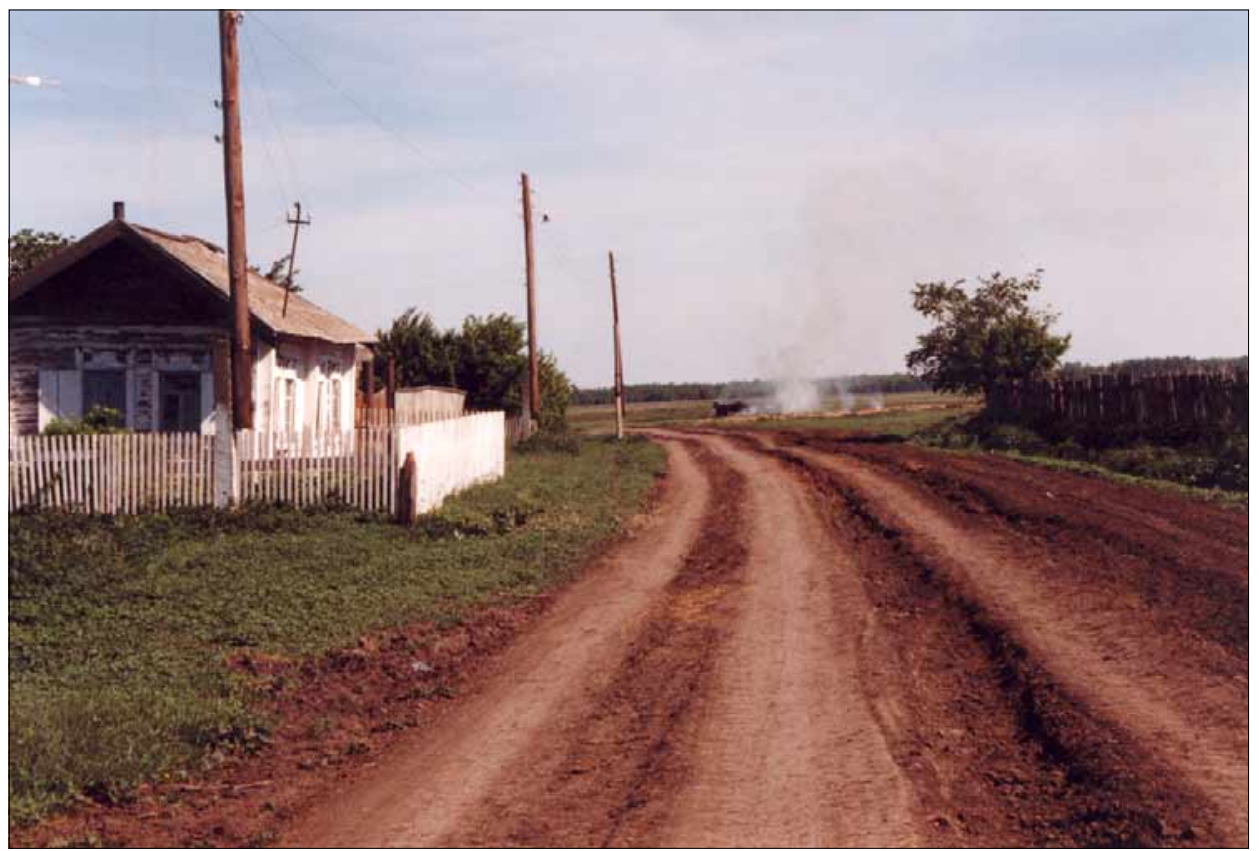

Foto 1. Rõžkovo külaots. Astrid Tuisu foto 1999. ERA, VF 3096.

Luteriusuliste asundustena Siberis rajatud külades on segaabielusid sõlmitud juba asunduse algusaegadest peale. Praeguste Rõžkovo elanike esivanemate hulgas on nii eesti, läti, soome kui ka saksa päritolu inimesi ning nad ei oska korrapealt oma rahvust nimetadagi. Etnilise identiteedi seisukohast on võimalik, et kultuuride kontaktalal elav, sageli segaabielust sündinud inimene võib end samastada kahe või enama rahvusrühmaga. Virulaste etnilise identiteedi ähmastumisele aitab kaasa ka asunike omapäraseks kujunenud keelesituatsioon. Nimelt ei kasuta sealsed vanema põlvkonna läti, eesti ja soome päritolu elanikud omavahelisel suhtlemisel vene keelt nagu see mujal Siberis tänapäeval kombeks. Domineerima pole pääsenud ka ükski külas räägitav keel. Kõik selle küla luterlased saavad üksteise keelest aru ning see võimaldab igaühel kasutada talle kõige omasemat keelt või vajadusel teisele keelele üle minna. Siiski võib virulasi pidada omaette pärimusrühmaks.

\section{Koolimeditsiinist ja rahvameditsiinist}

Koolimeditsiini ehk professionaalse teadusliku meditsiini tekkimise algusaegadest peale on püütud koolimeditsiini ja rahvameditsiini vahekordi selgitada. Koolimeditsiini valdkonnas tegutsevail ravijail on kõrgkoolist saadud 
ettevalmistus ja ühiskonna ametlik tunnustus, rahvameditsiin põhineb aga kogukonna või perekonna pärimusel, empiirilisel kogemusel, üleloomulikul ilmutusel. Tänapäeval kasutatakse termini rahvameditsiin kõrval ja asemel ka nimetusi etnomeditsiin, pärimusmeditsiin jt (vt Rørbye 2003: 12). Norra uurija Stein Mathisen (1989: 64-65) on kooli- ja rahvameditsiini erinevuse selgitamiseks toonud esile järgmised tunnusjooned:

Tabel 1. Professionaalse ja rahvameditsiini erinevused Stein Mathiseni (1989) järgi

\begin{tabular}{l|l}
\hline Professionaalne meditsiin & Rahvameditsiin \\
\hline haigus & tõbi \\
\hline ametlik & mitteametlik \\
\hline diagnoos & haigusseletuse andmine \\
\hline loodusseadused & üleloomulikud jõud \\
\hline ravimid, kirurgia & palve, loits \\
\hline ravimine & parandamine \\
\hline rehabilitatsioon & ime \\
\hline
\end{tabular}

Koolimeditsiini puhul rõhutab S. Mathisen selle põhinemist patsiendi biokeemilisel ravil ja tunnustatud loodusseadustel, kuid tema rahvameditsiini käsitlus on siinkohal jäänud ühekülgseks - asetades rõhu sõnamaagiale, jätab ta välja taimeravi, massaaži jms (vt ka Kõiva 1995: 177). Tegelikult on koolimeditsiin ja rahvameditsiin arenenud pidevalt teineteist mõjutades. Patsiendi seisukohalt polegi neil olulist vahet ja ta asetab rahumeeli rahvaarstilt saadud ravimi tohtri väljakirjutatuga kõrvuti:

[---] Samal viisi kui lekarstva balnitšnõi, vse propkami zakrõtõ, nii $i$ seegi, et vozduh nii tak papal bõ. Tjomnom meste deržat, vot lekarstvad on keik, ved pri svetle ne tjoržiš ${ }^{1}$ [---] (ERA, CD 462 (14) < naine, s 1926).

Ühe või teise ravisuuna eelistamine on eri aegadel sõltunud mitmetest teguritest. Näiteks 18. sajandi lõpul olnud Eestis iga maakonna kohta vaid üks arst, kelle abi olnud mõisnikulgi raske saada (Põvvat 1992: 48). Soomes olnud aastal 1883 vaid 53 ringkonnaarsti (Honko 1982: 62). Seega oli ravioskuste edasiandmine ja ravitsejate esilekerkimine sel perioodil tingitud praktilisest vajadusest. Riikliku meditsiini ja arstikutse tähtsuse kasv kutsus järjest enam esile professionaalsete arstide proteste teadjate, posijate, nõi- 
dade jms vastu (vt nt Foucault 2003: 463). 19. sajandi teisel poolel algas Eestiski seoses rahvusliku ärkamisega rahvameditsiini kui ebateadusliku ravitsemise väljatõrjumine. Ometi jäi kvalifitseeritud arstiabi kuni 1920. aastateni maarahvale suuresti kättesaamatuks (Kõivupuu 2000: 171). Siberi luteriusuliste, resp. eesti külade algusaegadel polnud elanikel võimalustki õppinud arstide poole pöörduda.

Asunike usuelu eest hoolitsemine jäi esmalt Moskva luterliku konsistoriaalpiirkonna pädevusse. Esialgse lahenduse tõi asundust aeg-ajalt külastav rändpastor, hiljem tegutses enamikus asundustes kohapeal köster-kooliõpetaja. Aastast 1863 hakkas soome luterlik kirik Siberi soomlaste hingehoiu eest hoolt pidama. Esmalt saadeti pastor Ida-Siberisse, kust usuelu suunamise raskuspunkt kandus 1880. aastate keskpaigast Lääne-Siberi asundustesse (Saari 1994: 14, 36).

Usu- ja hariduselu juhtimise kõrval jäi kiriku pädevusse ka hoolekanne haigete ja vaeste eest (vt Granö 1999: 129), mida toimetati oktoobripöördejärgse usuelu keelustamiseni. Seejärel pidid külaelanikud omapäi hakkama saama. Siberi kõrvalistes külades, nagu Rõžkovo (kõvakattega teed pole külani tänini ja sinna sõitmine sõltub suuresti ilmastikust) ei saa ka tänapäeval alati loota välisele abile.

Riikliku meditsiini võidukäiku inimteadvuses võib seletada uue ravimite põlvkonna - antibiootikumide - kasutuselevõtuga pärast Teist maailmasõda (Kleinmann 1980), aga ilmselt ka mitmete muude teguritega, nagu ravi kättesaadavuse ja pideva selgitustööga. Eestis vähenenud maa-arstide ja imeravitsejate juures käimine juba 1930. aastate paiku (Kõiva 1995: 176). Siberisse Rõžkovo külla jõudis riikliku tasandi arstiabi tõenäoliselt 1930. aastatel, kuid alles pärast Teist maailmasõda hakati riiklikku meditsiinisüsteemi jõudsalt arendama ning küla sai oma haigla:

[---] Esteks oli venelane tohter, vot ku ma olin veiksest päevadest, tian Litovkin, a siss oli üks naisterahvas, no see et kavva ei old. Vobšee naisterahvad kavva eivad old, je a siss nüid juba vot, nii, Van'a mul neljaskümnest kolmandast aastast, vot neljaskümnes kuvvendast aastast, siss juba oli, akušerka oli ja juba tohtred olivad, medsestra oli daže sial bolnitsas ja. A siis juba läks, üksvahe vobšee glavnõi vratš oli ja panivad haigeid lesima sinna bolnitsasse [---] (ERA, CD 458 (16) < naine, s 1923).

Tervishoiukorralduse paranemine ja meditsiiniabi kättesaadavamaks muutumine pole aga isegi hästiarenenud riikliku meditsiinisüsteemiga riikides kaotanud huvi alternatiivmeditsiini vastu (Alver \& Selberg 1989: 207). Tänapäevalgi on laialt levinud uskumus, et teatud hädade korral (nt roos - 
tuulest, veest, maast või pahast silmast saadud haigus) ei saa riiklikule arstiabile loota. Seda arvamust kinnitab ka Rõžkovo virulastelt kogutu:

Vaata on niuksed haigusest, et viiakse tohtri ette ja tohter ütleb: Ei me ei voi arsti, a minge, minge vanamuoridel, baabuškatel. Ja viiakse baabuškatel ja baabuška arstib, a tohter ei saa miski teha. Seda on old ja seda lieneb (ERA, CD 459 (8) < naine, s 1913).

Nõukogude süsteemile omaselt püüti uut arstimissüsteemi juurutada vana keelustamisega. Selle ülesande täitmine pärimuslike traditsioonidega külas ei kuulunud aga lihtsate kilda. Siberi külla saadetud venelasest arst oli ikkagi võõras, keda pimesi ei usaldatud (vrd Honko 1982: 59), kuigi vene keelest arusaamine virulastele raskusi ei valmistanud. Ametivõimud tunnistasid pärimusliku arstimistarkuse iganenuks ja tuntumad ravitsejad sattusid tagakiusatute nimekirja:

A siss jo hakkasivad nied vanamuorisi ved' hakkasivad pilkama ja nemad ei tohtind arstida. Siss jo ei tohtind. Kartsivad. Nüit enambi ei karda, a siss jo kartsivad. Siss moni sona ütlesid ei niiviisi ja sind voivad panna vot kinni [---] (ERA, CD 465 (29) < naine, s 1927).

Siiski ei sattunud Siberi eestlastest arvukad ravitsejad sama tugeva surve alla kui Siberi põhjarahvaste šamaanid, kes kuulutati rahvavaenlasteks: nad rikastuvat teiste arvelt, ravimise asemel kahjustavat inimesi. Šamaanidelt võeti ära rituaalsed esemed, nad vangistati või küüditati (Vallikivi 2005: 41). Ravitsejaid oli külades palju, nende tegevus polnud küll šamaanidega võrreldes nii nähtav ja atraktiivne, kuid teadmine ravitegevusele järgneda võivast karistusest ei saanud jätta pärimuse edasiandmisele mõju avaldamata. Ravitsejate tegevus oli karistatav kuni 1980. aastate alguseni, mil Leonid Brežnev andis rahvaarstide tegutsemiseks vabad käed (Kõivupuu 2000: 172). Eesti rahvaarste ja meediume uurinud Mare Kõiva tõdeb, et rahvameditsiini ja -arste soosivad ajad saabusid siis, kui rahvapärase arstimise järjepidevus oli jõudnud enamikus Eestimaa paigus katkeda (Kõiva 1995: 183). Tänapäeva stressirohke elu on tinginud rahvaravitsejate, ka uusravitsejate tegevuse elavnemise.

Nüüd taas virulaste pärimusrühma juurde.

\section{Ravitsemisoskus - üldteadmine või üksikute tarkus}

Ravitsemisoskus pole virulaste pärimusrühmas nagu mitmetes teisteski Siberi külades tänapäevalgi üksikute tarkade pärusmaa, vaid kuulub kogukonna üldteadmiste hulka. 
[---] Meil on külas niuksi pal'lu. [---] Vedoma Mari oskab, Miku Anni oskab, Petju Helena oskab, tema Poljaka, Ignatovitša Mari oskab, Pauliina oskab, a kes siin viel oskab, see Pahmernõi Vilma oskab siin otsas: ruosi, ehmatamisest, silmamisest, pistuksest. No oskavad, pallu oskavad inimesed. Daže Naaritsa Sanjagi oskab [---] (ERA, CD 459 (5) < naine, s 1913).

Viimati nimetatu - Naaritsa Sanja - on eelmainitutest põlvkond-paar noorem ja tema nime mainimisega püüab informant rõhutada ravitsemisoskuste edasikandumise järjepidevust.

Ravitsejate paljusus on varem olnud üldine ka mujal, nt Soomes, kus 19. sajandi algul ulatunud ravitsejate hulk 40 000ni, sajandi lõpuks olnud neid umbes 7000 (Paju 1989: 81; Lönnrot 1981 [1839]). Eestis olnud posimine või sõnamine 20. sajandi alguses üldlevinud, ainuüksi Võnnu kihelkonnas loetletud viimase saja aasta jooksul kokku umbes 700 ravijat (Kõiva 1995: 176). Kõigi tegutsenud rahvaarstide kohta meil ammendav teave lihtsalt puudub. Näiteks 1925. aasta arhiivisäiliku järgi oli Eestis 395 rahvaarsti, dateerimata säiliku järgi 438 (Põvvat 1992: 48). Esimese ülevenemaalise rahvaloenduse andmetel aastast 1897 oli Tobolski kubermangus üle 500 ilma ametliku loata meditsiinivallas tegutseja (Perepis 1905: 228-229, 248-249).

Arhiivisäilikud, rahvaloenduse andmed jms ei kajasta ilmselt tegelikku olukorda ei meil ega mujal maailmas. Arvata võib, et ravisõnad polegi olnud niivõrd suletud, ainult teatavate oskuste ja omadustega inimestele teada olev pärimus, nagu uurijad mõnigi kord on väitnud (vt nt Kõivupuu 2000: 35; Kõiva 1992: 117). Ilmselt võib seesugust teavet pidada suletud pärimuseks vaid piirkonniti või isikuti. Siberi eestlastelt 20. sajandi viimasel kümnendil talletatu põhjal (aga varasemast ajast on andmed ebatäielikud või puuduvad hoopis) võib öelda, et tol ajal oli õigeusklike naabrite mõjuväljas kasvanud Siberi eestlaste sõnamaagia tundmine märksa üldlevinum kui Kodu-Eestis (vrd Kõiva 1995: 183). Siberis lõunaeestlaste asutatud külades (nt Semjonovka, Zolotaja Niva) suhtuti ravisõnade edasiandmisse siiski ettevaatlikumalt (vt Korb 1996: 12) kui põhjaeestlaste asutatud külades. Analoogiline tundub olevat olukord ka Eestimaal: Lõuna-Eestis on ravisõnad olnud suletum pärimus kui Eesti põhjaosas.

\section{Ravioskuste ja -sõnade edasiandmine ning vastuvõtmine virulaste pärimusrühmas}

Ilmari Manninen (1925: 454) märgib, et juba kõige algelisemal inimesel on teataval määral instinktiivseid arstimisoskusi, mis on osutunud temale otstarbekohasteks ja mida ta tarvitab edasi ilma nende põhjendamisele mõtle- 
mata. Seega omandab konkreetse pärimusrühma või perekonna liige mingi osa rahvameditsiinilistest teadmistest pärimuslikult. Rõžkovo virulaste pärimusrühmas antakse ravisõnu ja -oskusi edasi samuti kui muud pärimuslikku teavet - laule, jutte, kalendritavandit (vrd Templing 2005: 215). Muidugi võib igast kogukonnast, ka virulaste omast, leida võimekamaid ja vähem võimekaid ravitsejaoskustega inimesi, nagu seda võib öelda ka rahvajutustajate, laulikute või traditsioonilise kombestiku tundjate kohta.

Kui pärisin, kas igaüks saab arstida, arvati külas üsna üldiselt:

[---] Saab. Vaikku kes. Ku sa, näe, tahad, küsi. Ta sul kirjutab ja sa lued ja void arstida teise inimese [---] (ERA, CD 459 (8) < naine, s 1913).

Teise virulaste seas levinud arvamuse kohaselt võib sõnu edasi anda siiski vaid endast nooremale:

A tohib nuoremal. Vanemal ei, a nuoremal. Seda voib opetada vai kellele. (ERA, CD 447 (34) < naine, s 1928).

[---] Nad on jumalasonad. Neid võib hot' kellel. [---] Kes tahab oppida, las opib. Mis jumalasonad on pannetud, neid võib keikidel opetada [---] (ERA, CD 472 (22) < naine, s 1921).

Väidet, et need on jumalasõnad ja neid võib vabalt edasi anda, kuuleb Siberi vanemates külades üpris sageli. Loitsutekstide samastamist jumalasõnaga mõjutab tavainimeste hulgas ilmselt asjaolu, et aastasadu on Euroopa kultuuriruumis loitsudena tarvitatud evangeeliumide ümberkirjutusi, palvetekstide osi jms (Kõiva 1998: 200). Loitsutraditsiooni on aegade jooksul lisandunud erineva taustaga kristlikke tekste (nt Bütsantsi-mõjulised idaslaavi ravisõnad, kus domineerib musta-punase ja kuldse värviga seotud sümboolika, kinnitusvormel aamen; katoliikluse mõjul pühakute Peetri, Paveli, Maarja ja Jeesuse poole pöördumine; loitsulegendid) (Kõiva 1992: 119-123). Loitsuna on kasutatud ka Meie Isa palvet, mis pidi stabiliseerima igasuguse kriisiolukorra (Kõiva 1999: 118).

Ravisõnade abil toetub kõigile kättesaadavale Jumala abile ka Rõžkovos üldlevinud arvamus, et jumala abi iest ei maksu ei voeta (ERA, CD 451 (10) < naine, s 1922). Kohalikus kontekstis tähendab see asjaolu, et ravitseja ise tasu ei küsi, mis ei välista muidugi tänutäheks söögipoolise, raha vms annetamist. See tees sarnaneb ravitsejate omale, kes tunnetavad end meediumina, inimestele jumala abi vahendajana (Alver \& Selberg 1989: 211).

Üsna loogiliselt seostub eelnimetatuga ka laialt levinud uskumus, et ravitseja saab aidata vaid ristitut - taevaste jõudude kaitse alla antut (vt nt Valk 1998: 141). Virulased märgivad sageli, et nõdrausulisele ravisõnad ei 
aita ja selle kinnituseks on paljudel informantidel konkreetne näide varnast võtta:

[---] Meil Andre oli veikene, ta oli haige ja kohe, kui Liida läks vanamooril, vanamoor kohe küsis, kas on ristitatud vai ei. Liida ütleb, ei ole. Estiks ta ristitas, siss hakkas arstima teda ${ }^{2}$ [---] (ERA, CD 464 (25) < naine, s 1927).

\section{Rõžkovo ravitsejad}

Rahvaarste on ravivõtete alusel liigitatud:

1) ekstaasi abil ravijad,

2) verbalistid (sõnade ja loitsudega ravijad),

3) herbalistid,

4) kätega ravijad ehk manuaalterapeudid (vt nt Tuovinen 1984).

Siberi eestlastest ravitsejate hulgas ekstaasi abil ravitsejad puuduvad. Et ravitsemisoskused võib omandada igaüks, kel selleks soovi, ei kehti tänapäeval Rõžkovo virulaste pärimusrühmas arusaam rahvaarstist kui silmatorkava välimusega marginaalsest isikust, kellele ravijavõimed on sündides kaasa antud. Samuti ei peeta tõenäoliseks, et arstikutse on omandatud jumaliku ilmutuse või religioosse kogemuse abil (vt Kõivupuu 2000: 53; Paju 1989: 81). Üleloomulikke võimeid omistavad virulased tarkadele, kes tundsid karjanõidust, oskasid varga kinni võtta vms, ning nõidadele (enimlevinud nimetus kaldun, galdunja), kes võisid põhjustada inimese ja looma haigestumist või surma. Tarkadel ja nõidadel tehakse Rõžkovos sisulist vahet (terminite kohta vt Eisen 1919: 14; Laugaste 1936: 516-524) ning neist mõlemast räägitakse tänapäeval pigem minevikuliselt. Rahvaarstide lugudes võidakse küll rõhutada ravitseja võimekust hädadega, ka üleloomulikku päritolu hädadega, toime tulla, kuid samas kinnitatakse, et tema oskused on omandatud õppimise teel, nt:

[---] Siin oli üks vanaema, ta korjas ja arstis kovasti inimesi.

- Mis ta nimi oli?

- Liisa.

- Eestlane oli või lätlane või?

- Iestlane, a-ah. Ta käis pallu pallu inimesi, haigeid, keiki arstis igatmuodi.

- Mis hädadega siis tema juures käidi? 
- Pallu hädadega, pallud. Moned olivad koguni viletsas olemises, a tuodi, ta arstis ära. Tema meheisal oli olnd raamat, sellest ta oli oppind arstima. Ta arstis ehmatamisest, sial tuulest, venitamisest, ruosi - no keigist, keigist.

- Nii et tal olid siis sõnad või?

- Noh sõnad olid.

- Ja ja taimi kah siis kasutas?

- Jaah. [---] Tal tuodi teistest küladestki niukene, et pidi, üks tuodi, kui sie piaga oli kovasti raskesti haige. Ta ütleb, et kes toi, et jäta teda siia. A sie tuoja ütleb: kui te temaga hakkama saate. - Jah, saan hakkama. Siis jättis tema, ta kuu aega oli temal, ta küttis sauna ja sial saunas teda arstis. Tuldi järgi - ta oli terve.

- Aga kas laste vastuvõtjaid ka oli?

- A vot sie vottis lapsi ka vasta, see Liisa. Arstid siin ei olnd, a ta oli lapsi vastu võttand (ERA, CD 451 (10) < naine, s 1922).

Taluperedes omandati olulised oskused eluga toimetulemiseks enamasti teismeliseeas. Nende oluliste teadmiste hulka kuulusid ka rahvapärased ravimisviisid-võtted. Osa inimesi on neid teadmisi ka kohe kasutama hakanud, seega on teateid ka noortest ravitsejatest (vt nt Templing 2005: 214, 226). Levinud tavaarusaam eeldas ravitsejailt siiski suhteliselt soliidset iga. Näiteks Eesti andmed 1929. aastast näitavad, et suuremal osal ravitsejaist oli vanust üle 40 aasta (Rooks 1929: 378). Ühelt poolt oli noorel ravitsejal vähese elukogemuse tõttu traditsioonilises külakogukonnas raske end maksma panna, teisalt ei olnud uuele ja moodsale avatud noored ise valmis seesugust ametit pidama. Rõžkovos kahetses üks vanem informant nüüdki kibedasti, et oli omal ajal ema soovitusele ravisõnad selgeks õppida tõrjuvalt reageerinud:

[---] Minu mamma ajas ikke, et mine, Liisa, kirjuta üles nied arstimised. Ma ütlen, ega ma vanaema ole, et ma lähän kirjutama. A nüid oleks keik kolband [---] (ERA, CD 451 (10) < naine, s 1922).

Analoogilisi kirjapanekuid võib leida ka Eesti Rahvaluule Arhiivi Eestis kirja pandud materjali hulgast:

Vanaema M. Vuks rääkis ju niiviisi, et tema oles selle arstitarkuse kõik edasi andnu, aga jörgmisele põlvele ei saa anda. Ja ta tahtse minule anda noid sõnno, a kus mina - ma oll noor ja tähtsust täis niisugust vana usku veel... [---] (RKM II 395, 341 (1) < Võnnu (1986)). 
Viimane arhiiviteade viitab ühtlasi laialt levinud uskumusele, mille kohaselt ravitseja pidanud valima enne surma välja järglase, kellele maagilised sõnad ja arstimistarkus usaldada. Rõžkovo virulastelt talletatud materjali põhjal tundub, et ravitsejate paljusus ja ravitsemisoskuste kõigile soovijaile edasiandmine elimineeris selle kohustuse juba eos.

Põhjusena, miks ravitsemisest pole alati abi olnud, on virulaste traditsiooni juurdunud teadmine, et patsiendil tuleb paljude ravitsejate seast leida nt verd mööda ravitseja. Näiteks korduvalt roosihaigust põdenud naine pöördunud alati sama ravitseja juurde tagasi - kelleltki teiselt ei uskunud ta abi saavat.

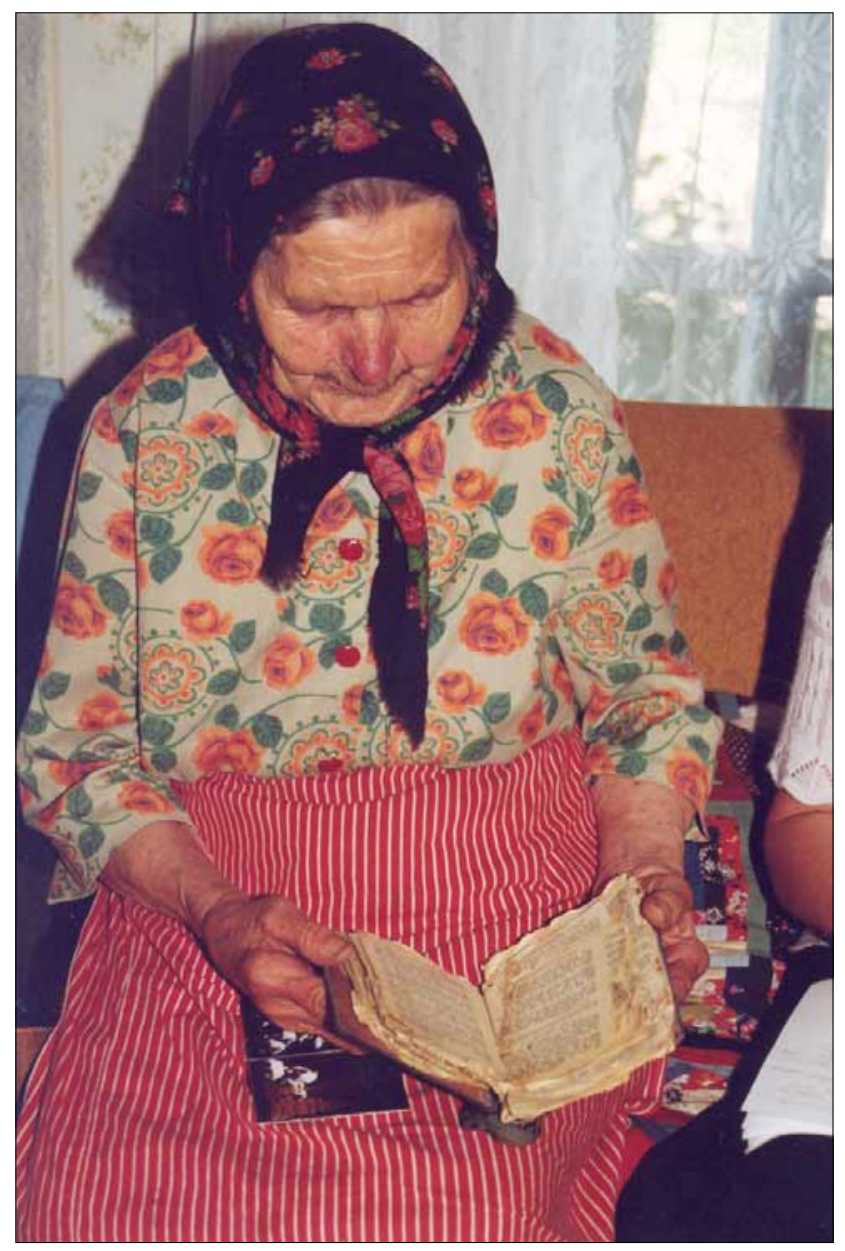

Foto 2. Ravitseja Mari Vedom. Astrid Tuisu foto 1999. ERA, VF 3098. 
[---] Igaühel ei aita igaühega. Vot seesama ruoski. Mõnikene ku lueb, nii hakkab hullemini valutama. Kelle veri ei ole selle järel vai mis ei lähe, et...

- Nii et pead vaatama, kelle lugemine sulle aitab siis?

- No lued, ku ta aitab, sis ta kohe aitab. A kui ei aita, sis enamb ei saa minna, sis hakkab veel rohkem valutama neist kohe, kohe tunned sis (ERA, CD 468 (5) < naine, s 1915).

[---] Meil ode oli, nüit ta on surnd, andku jumal talle kerget maad ja kerget puhkamist. Tal oli ruos rinnas. Laps imes $i$ rinnas oli ruos. Ta käis mitmel, mitmel. Ta ise oskas ja ma oskasin i paljul käis $i$ keski ei aitand. Ja rääkisivad, otsa pial elas siin ka meie uulitsas Kuulmani Roožuk. Tal käis, nigu sinna oleks jäändki [---] (ERA, CD 447 (34) < naine, s 1928).

Ravivõimed kadunud pärimusekandjate arvates ravitseja hammastest ilma jäädes ja tervise halvenedes (Kõivupuu 2000: 55).

A isi ütlevad, sellel [st selle ravimine] ei aita, kellel ei ole hammaid enamb suus [---] (ERA, CD 475 (22) < naine, s 1927).

Hoolimata sellest teadmisest on mõned Rõžkovo ravitsejad, näiteks Mari Vedom, oma ravisõnu kasutanud ka oma viimastel eluaastatel peaaegu jalutu ja hammastest ilmajäänuna, lootuses, et need hädasolijat ikka aitavad. Üldlevinud on ka arvamus, et ravitseja ei saa ennast ravida, kuid mõni virulastest ravitseja on ravimist ka omal nahal proovinud ja edukalt toime tulnud.

\section{Haigusseletused ja ravivõtted kogukonnas}

Ravitsejatel on läbi aegade olnud tähtsal kohal haiguse tekkepõhjuse otsimine (Honko 1960: 83-84). Rahvauskumuse kohaselt pärineb enamik haigusi tuulest, veest, maast, surnutelt, kurjast silmast või nõidusest. Et haigus kardab oma nime ja päritolu avaldamist, võis haiguse päritolu määramine saada arstimise tähenduse (Manninen 1925: 453; Loorits 1990: 61-66). Tuntumatest rahvapärastest arstimisviisidest, mis on teada ka Rõžkovo virulaste juures, toon välja järgmised:

1) arstimisvahend olgu sealt, kust haiguski;

2) arstimisvahend olgu samasugune nagu haiguse sümptoomid või haige koht;

3) arstimisvahend peab olema kangem kui haigus, et seda ära ajada või tappa (vt Manninen 1925: 455-458). 
Rõžkovos raviti näiteks lapse koeraviga paigas, kus koer oli surnud:

[---] Kus koer on loppend - ja seda ma tian totšnost - ja ära mädand juba, no vai on ta sial, et liigutad tema ära ja siss sial käid last oeruma, nigu no oerud selle koha pial. A sel lapsel tuleb, tal aga koht tuleb, näe, suur, see on, ütlevad, koerahaigus. Kolm korda tarvis käia vai üheksa ja pä̈̈seb laps terveks [---] (ERA, CD 459 (20) < naine, s 1913).

Veest saadud sügeleva nahalööbe korral oli arstimisvahendiks sool, millega nahka hõõruti, kuid parema tulemuse saavutamiseks läks vaja ka ravisõnu. Sool tuli visata vees samasse kohta, kust arvati häda olevat saadud.

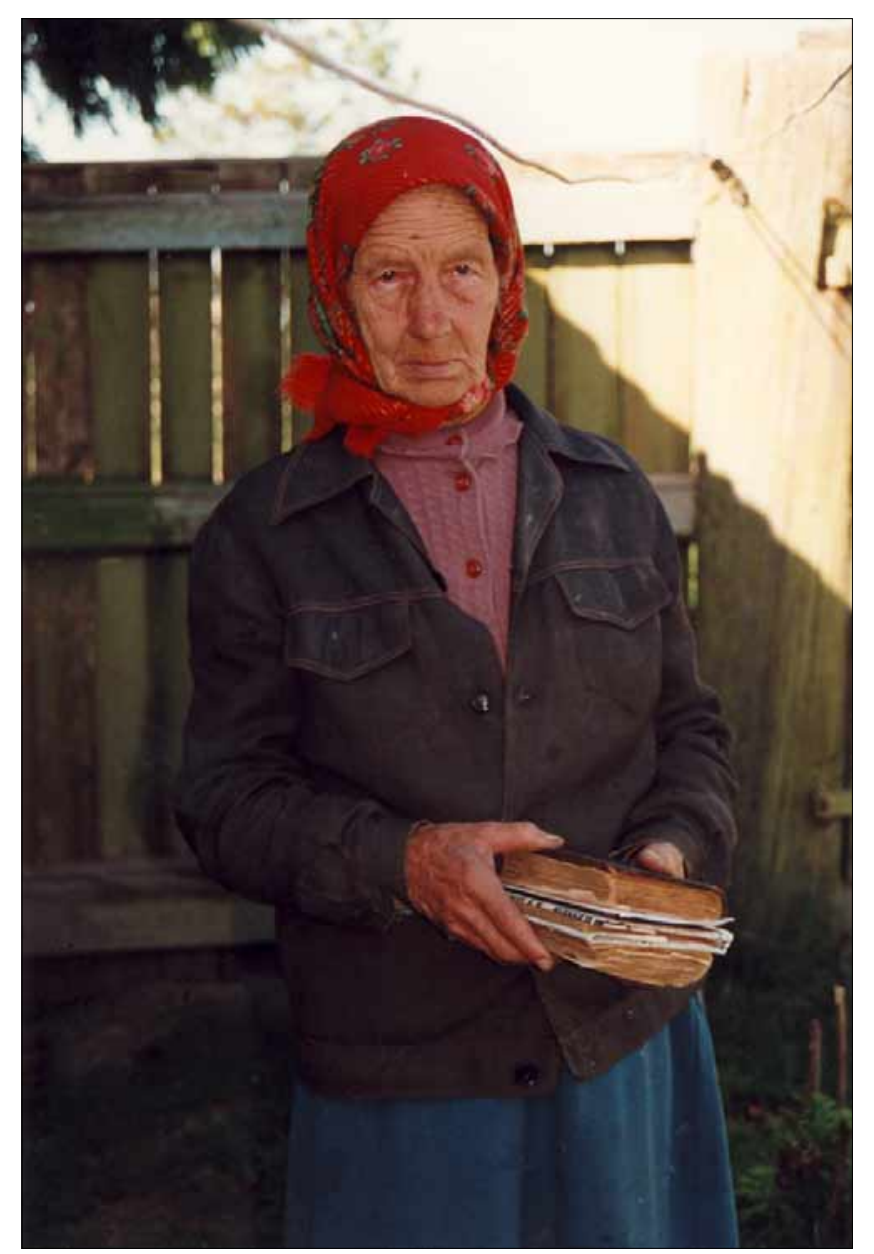

Foto 3. Mari Blumfert teab nii eesti-, soome-, läti- kui venekeelseid ravisõnu. Anu Korbi foto 1999. ERA, VF 1754. 
Anu Korb

Pisti raviks kasutati terariistu:

A ku on pistus sul, nii panevad üheksa noela. Näe, stokana panevad üheksa noela, vett panevad ja üheksa noela sinna sisse. A ma vot ei vaadand ja ei tia, kas pannakse - tarvis Helenalt küsida - see terav ülesse või terav alla. Siis luetakse sinna, luevad pial ja siss seda vett tarvis juua. A siss jälle kes kui, kes loeb niisama, annab vett, kes nuaga torgib, see kus on. See pistuksest keigil viisi tievad. Oi-jah! (ERA, CD 459 (23) < naine, s 1913).

Maagilist menetlust tuli traditsioonikohaselt sooritada kolmel korral, sama arv kordi pidi lugema üht ja sama loitsu. Ravimiseks vajalikku ainet või eset võeti vastavalt kolm või üheksa korda - kõik see on tuntud paljude rahvaste traditsioonis (vt nt Mansikka 1929; SKVR 1908-1948).

Arvudel põhinevate loitsude puhul, millega sagedasti ravitakse nahahaigusi (nt roos), traumasid (nt nabavenitus), kõhutõbesid (nt pist), mütoloogilise taustaga haigusi (nt rabandus, lendva), mitmeid meelehaigusi (nt ehmatus), prevaleerib loendamine ühest üheksani või vastupidi - üheksast üheni (Kõiva 1999: 116-118).

Ravisõnade lugemine peaaegu kuuldamatult on kombeks Rõžkovoski, kuigi tänapäeval puudub neil teadmine valjusti loetud sõnade maagilise jõu võimalikust kadumisest (vt Kõivupuu 2000: 174).

Virulaste ravivõttestikus ja ravisõnades on märgata siiski pärimuse taandumise tententsi. Näiteks arvatakse olevat üheksat liiki roosi, kuid nimetada osatakse tavaliselt kolm: sinine, valge ja punane, mõnikord ka must. Haiguskirjeldused on üksteisega võrdlemisi sarnased. Näiteks roosiraviks kasutatakse põhiliselt ravisõnade lugemist vee või punase riide peale (vt ka Veidemann 1985: 136-139). Üldiselt teatakse, et ravivette tuleb panna nii soola kui ka üheksa söetükki, kuid tänapäeval jäetakse süsi sageli panemata või mugandatakse menetlust ja asendatakse süsi põlema süüdatud tiku vette viskamisega.

Roosihaiguse sõnu teavad paljud, kuid põhiliselt kasutatakse loitsude levinuima tüübi "Jeesus läks üle mäe" variante (Veidemann 1985: 141):

Jeesus tuli Siinani mäest alla,

kolm ruosi käes.

Üks oli sinine, üks oli punane ja kolmas valge.

Maha viskas sinise, maha viskas punase,

maha viskas valge.

Need lilled olid pealt ladvata, seest südameta ja alt juureta.

Alane, alane, alane kivi alla, 
üheksa kadaka puu juure alla.

Aamen.

Kolm korda lugeda tsaiu piale, või piale lugeda kolm korda või kaltsu piale ka lugeda kolm korda. Ja siis sülitad maha: "Kõik sitad mingu minust iemale!" Pahemasse puole sülitad: "Mingu kõik sitad iemale minust, tulgu tervis tagasi!" (EFA I 38, 123 (7) naine, s 1913).

Vanemaid, dialoogil põhinevaid loitsutüüpe (vt Kõiva 1992: 124) tuntakse tänapäeval Rõžkovos vähe. Sel viisil ravitakse siin näiteks pistihaigust:

[---] Ma küsisin talt: Mis sa pistad? A ta ütleb, et ma pistan pistuksest. Mis tarvis kolm korda küsida: Mis sa pistad? - Pistuksest. - Mis sa pistad? - Pistuksest. Nii, nii ja nii ja nii. A siss ta ütleb mulle: Ma pistan iaks ja eluks ajaks. Ja siss lueb vette ja annab juvva ja tuleb paremb [---] (ERA, CD 459 (6) < naine, s 1913).

Omi asunduskülades hästi tuntud külmtõbe (vt Korb 1998: 63-65) virulased ei tea, kuid vanemast traditsioonist on siin üllatavalt elujõulisena püsinud mütoloogilise haiguse lendva (med lumbago, kohapealsed nimetused lendav, lendev, haavatus, paralitš) haigusseletused ja ravivõtted. Lendva nimetuse all tuntakse järsku tekkivat ägedat nimmevalu, mis võib tabada eelnevalt täiesti terveks peetud inimest või looma ning haigus võib lõppeda surmaga.

[---] Lendva, näe, vast see ei ammu, nüid teine aasta on, ku meie uulitsas, sial, kus minu talu on, sial miuke tubli mies Gulbi Valodja oli, a Mari, näe, jäi nüid sinna talusse. Ommiku ajas lehmad karja ja läks rohtu hobusel tuoma, terve tubli punane mies, et ma ei oska ütelda, vähe niukse mehesid on, läks terve ja tuli kodu ja pääsis aga tuppa, tal plooho, plooho i kukkus divaana pial ja suri, sest see oli lendav. Vot lendvast tievad pallu meie külas. [---] Kui tabab sul nii mielekohta vai südamesse, kohe kukud ja sured (ERA, CD 459 (10) < naine, s 1913).

Lendva põhjustajaks peetakse pahasoovijat inimest. Rõžkovos ei räägita lendva puhul küll valla päästetud nõianoolest (vt nt Loorits 1990: 63; EE 1990: 485), pigem seostatakse toimingu läbiviimist teatud inimestega (nimetatud goldunja) kaasas käiva sunnina - kes kord on vastava oskuse omandanud, ei pääse sellest enam vabaks.

[---] Ta lassi seda haigust, lendvat vai kui ütelda. [---] Luomade pial ja inimeste pial. No need nägivad, kui tema lasi. Juuksed oli tommand olade pial ja puhund ühtepuole, teisepuole ja. Oli ta oige vai ei olnd, ma ei tia. Niiviisi rääkisivad inimesed.

- Mis siis juhtub, kui lendva on? 
- Noh jääb haigeks, luoma pial kui läksi, luoma ja lehm jäi kohe haigeks. Süöma ei hakkand ja suust hakkas külm õhk tulema ja. [---] - Kes lendvat teeb, kas see teeb nimelt kellelegi või läheb lihtsalt? - No ta laseb tuule, kuhu läheb. [---] No sonad on muidugi, ega ilma. [---] Ta on oppind, ta ütlevad, ta ei saa rahu. Ta piab seda tegema. [---] No ta oli vist [---] vana piru sisse last endale. [---] (ERA, CD 451 (11) < naine, s 1922).

Ometi ei piisa informantide sõnutsi lendva laskmiseks üksnes pahasoovijast, vaja on ka vastavaid ilmastikutingimusi:

[---] Iga pääv ta ei saa teha, a kui on severas veeter. Vot siss voib ta lasta. [---] Pääseb inimese pial, pääseb luoma pial. [---] (ERA, CD $464(28)<$ naine, s 1927).

Külas osati nimetada ka ravitsejaid, kellelt lendva vastu abi võis saada. Lendvasõnad, nagu muudki ravisõnad, loeti sageli vee peale, mida haige pidi sisse võtma või millega tal tuli end pesta. Looma raviks kasutati lisaks ka kangemaid vahendeid, näiteks:

Lehmal oli, siis ma panin piima ja andsin ja muna ja ee poorohhad, kui ütelda, püssirohtu. [---] Ja siss, en oska ütelda, ütlen veneks pautiinat. [---] Vot seda kah pidi sinna, pautiinat, veneks nad on pautiinad, a, iestiks, too ma äkist en oska ütelda - võrgud. Neid on prigonas ja i tuaski neid on. [---] (ERA, CD 456 (28) < naine, s 1921).

\section{Ravitseja rahvus, ravisõnade keel, loitsude suuline ja kirjalik levik}

Ravitsejalt loodetakse saada eelkõige abi. Rõžkovo virulaste kogukonnas pöördutakse esmalt enamasti omade hulgast pärit usalduse pälvinud ravitseja poole. Teisest kogukonnast või rahvusest ravitseja tuleb kõne alla raskema haiguse või keerulisema probleemi korral. Tõigale, et teisest rahvusest ravitsejatele on sageli omistatud tugevamaid ravivõimeid ja suuremaid oskusi, on osutanud mitmed rahvausundi-uurijad (vt nt Loorits 1928: $17 \mathrm{jj}$ ). Virulased otsisid abi ka naabritelt lätlastelt ja lähedal asuvatest vene küladest:

No siin oli veike küla üks, kutsuti Kudrinsk. Sialt käis, sial oli misle tark ja vana miesterahvas, arusaaja kovasti. Sial käidi, vahest tuodi siia teda. 


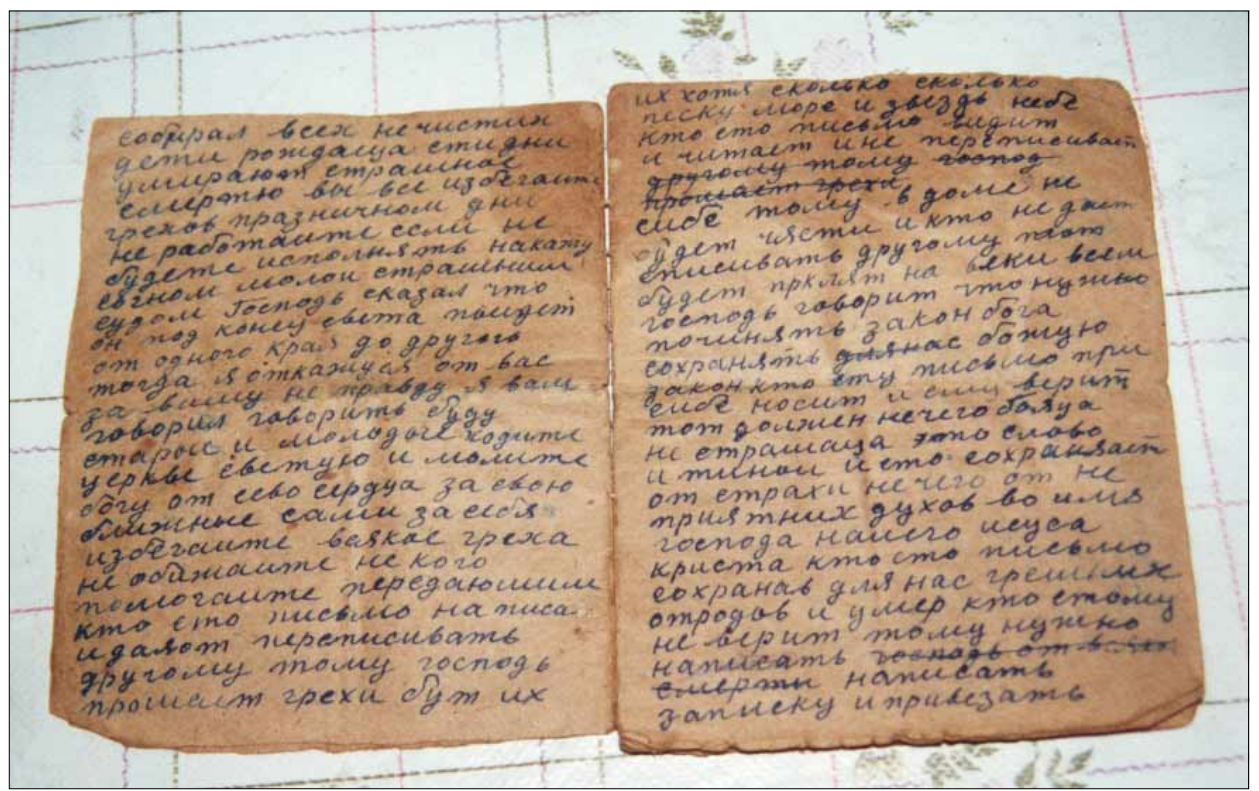

Foto 4. Mari Blumferti venekeelne kaitsekiri. Anu Korbi foto 2000. ERA, VF 3279.

- Mis hädadega tema juures käidi siis?

- No venitamisest käidi ja kui öeldi pahast silmast ja. [---] Kes oskab arstida, see näeb inimest pialt, mis tal on häda. [---] Vaatab ja ta saab kohe aru, mis sul on häda. Nigu arst (ERA, CD 451 (18) < naine, s 1922).

Venelastest ravitsejatega võidakse seostada ka eesti traditsioonis üldtuntud ravivõtteid:

[---] Mul oli peremehel siin käe peal üks aasta, nahk läks ärä, keik kondist saa'. Miski ei aita, miski ei aita. Tuli üks vana naisterahvas, ta meie küla inimene ei olnd, võóras venelane. Me näitame tal seda kätt, ta ütleb, ooi, see aknahigi võtke, sellega määrige. Sellega hakkasime määrima ja paranes (ERA, CD 469 (24) < naine, s 1922).

Enesestmõistetavalt on ka virulased ise jaganud oma arstimistarkusi kogukonnast väljapoole. Näiteks:

[---] Ma olin neli aastat tagas Kruutus bolnitsas, lesisin siin oma polvedega, mul polved kovasti valutavad. Nii üks naisterahvas, ta venelane. A, a kes see jäi haigeks sial. Ma lugesin temal. Ja omas 
Anu Korb

palatkas kellega olime. Ja siss sie teine oli nuoremb, küsis keik. Mul on i veneksi ja viruks ja keikis viisi. Ta kirjutas keik ülesse [---] (ERA, CD 447 (34) < naine, s 1928).

Loitsude kirjalik fikseerimine on olnud tuntud paljudel rahvastel. Näiteks eesti loitsupärimust uurinud Mare Kõiva andmetel on soome loitse endale kopeerinud ja kasutamiseks varunud nii rahvaarstid kui ka lihtsalt loitsimishuvilised (Kõiva 1995: 188).

Uurijad on juhtinud tähelepanu ka asjaolule, et ravitsejad on sageli olnud keskmisest haritumad (vt nt Templing 2005: 214-215). Seevastu rõžkovolaste vanema põlvkonna esindajate kooliharidus on sageli jäänud lünklikuks. Teksti kirjapanek valmistab nii mõnelegi neist tõsiseid raskusi. Seega on seal ravisõnad levinud tavapärasest sagedamini suuliselt. Kuuldelisel teel õpitud loitsude (sageli oli nende hulgas ka võõrkeelseid) tähendus võib olla suuresti moondunud (vt nt Kõiva 1992: 122). Loitsudes on läbi aegade kasutatud ka sisult tähenduseta sõnu või terviktekste. Mitmekultuurses keskkonnas on keeleline ümberlülitumine tavapärane ja samale seaduspärasusele alluvad ka loitsud. Virulaste suuliselt esitatud või kirja pandud tekstides tuleb ette vene-eesti-soome ja vene-eesti segakeelt, ladina tähestik võib vahelduda kirillitsaga, eestikeelne tekst olla kirjutatud vene tähtedega, nt:

[---] Ma kirjutasin, no ta iestiks, a no vene tähtedega. [---] (ERA, CD $472(23)<$ naine, s 1921).

Ravisõnade õppimisest rääkides rõhutatakse, et sõnad antakse üldjuhul edasi selles keeles, milles need on õpitud. Et virulased saavad hakkama nii eesti, soome, läti kui ka vene keelega, on sealsete ravitsejate pagasis loitse kõigis neljas keeles. Välitööl fikseerisin näiteks eestikeelsete ravisõnade kõrval soomekeelsed sõnad tuulest tulnud haiguse vastu, venekeelse loitsu pahast silmast saadud häda vastu, lätikeelsed venituse- ja roosisõnad - viimased tundusid olevat kogukonnas eriti hästi tuntud, nt:

Mūs' kungs Jēzus Kristus brauc' pār jūr'. Devin̄ roz' rokās. Trīs zil's, trīs, trīs balt's un trīs sarkan's. Zilā iznīk', baltā izplūst' sarkanā izžūst. Izpūt roz ārā kā vec' mēness, kā vec kok [arusaamatu sõna] izpūst, no Māra vārd' āmen, no Māra vārd' āmen, no Māra vārd' āmen ${ }^{4}$ (ERA, CD $311(24)<$ naine, s 1922).

[---] Jēzus stāv Golgāt's kalnā, berž trīs roz’s. Vienu zilu, vienu sarkanu, vienu mellu. Noberzēj' rozi. Siis isameid loed ära. Ja nü̈̈ keik, kolm korda või nii.

- Issameiet ka loed läti keeli või? 
- Nu jah. Mūs' tēvs debesīs svètîts lai top tavs vārds lai nāk tav' valstīiba mūǔz̆gi mūžam āmens ${ }^{5}$ (ERA, CD 465 (41) < naine, s 1929).

Ka loitsu tõlkimine suupärasemasse keelde oli kogukonnas aktsepteeritud. Kui soome- ja lätikeelseid ravisõnu teadnud naiselt küsisin, kas informant teab ka eestikeelseid ravisõnu, vastas ta:

[---] No kui sial teda kierad, noh. Sie tarvis jälle mottelda, teda kierata viruks, nied sonad.

- Kas teda võib keerata?

- A miks ei või. [---] Kierata nied sõnad keik, kui ütelda vene viisi perevestii, siis oppida. [---] Kieled on niiviisi, et üht kielt sa räägid, ta tuleb, kui ütelda vene viisi, skladnosti, a kui tema tied teise kiele pial, seal tarvis teda muuta jälle. [---] (ERA, CD 469 (22) < naine, s 1922).

Seevastu paljud ravimtaimede nimetused on rõžkovolaste keelepruuki juurdunud venekeelsetena - neid on alles võõrsil tundma õpitud (vt Viikberg \& Vaba 1984: 222) või on nad Siberi viljakal maapinnal lopsakama vormi tõttu Kodu-Eesti taimedega raskesti samastatavad. Ilmselgelt võib siin täheldada ka venekeelse meedia ja kirjanduse mõju.

\section{Kokkuvõtteks}

Vanemate raviviiside-võtete ja ravisõnade tundmine on Rõžkovos, nagu Siberi eestlastel üldse, püsinud kauem kui Kodu-Eestis. Ühelt poolt tingis seda praktiline vajadus, teisalt oldi sõnamaagia suhteliselt hästi säilitanud naabrite mõjuväljas.

Virulaste kogukonnas ei torka rahvaarstid eriliselt silma, sest ravitsemisoskus on vähemalt vanema põlvkonna esindajate arvates igaühele kättesaadav ja õpitav. Ravisõnu on edasi antud enamasti suuliselt, kuid hilisemal perioodil on neid ka kirja pandud. Mitmekultuuriline ja -keeleline keskkond on soodustanud enam ka naabrite ravisõnade (sealjuures eri keeltes) õppimist. Tavapäraseks on peetud ka ravisõnade tõlkimist.

Virulaste traditsioonis on hästi püsinud mõned vanapärased haigusseletused (nt lendva) ja ravivõtted, kuid üldisemalt võib Rõžkovo ja Siberi eestlaste ravitsemistraditsioonis märgata traditsiooni taandumist: ravitsejate arvu vähenemist, ravivõtete mugandamist, loitsutüüpide ja tekstivaliku ahenemist. Sellele on suuresti kaasa aidanud riikliku meditsiiniabi tõhustumine ja aastakümneid kestnud ühiskondlik-poliitiline surve rahvaravitsejatele. 
Et külakogukond aktsepteeris eakamaid ravitsejaid, pole noored pidanud ravisõnade õppimist vajalikuks seni, kuni nad ise vanemaks saada jõudsid. Selleks ajaks oli aga osa pärimusest päästmatult hääbunud. Ilmselt pole rahvapärane ravitsemisoskus siiski päriselt kadumas, pigem teisenemas seda suuresti ka massimeedia mõjul.

\section{Sõnaseletused}

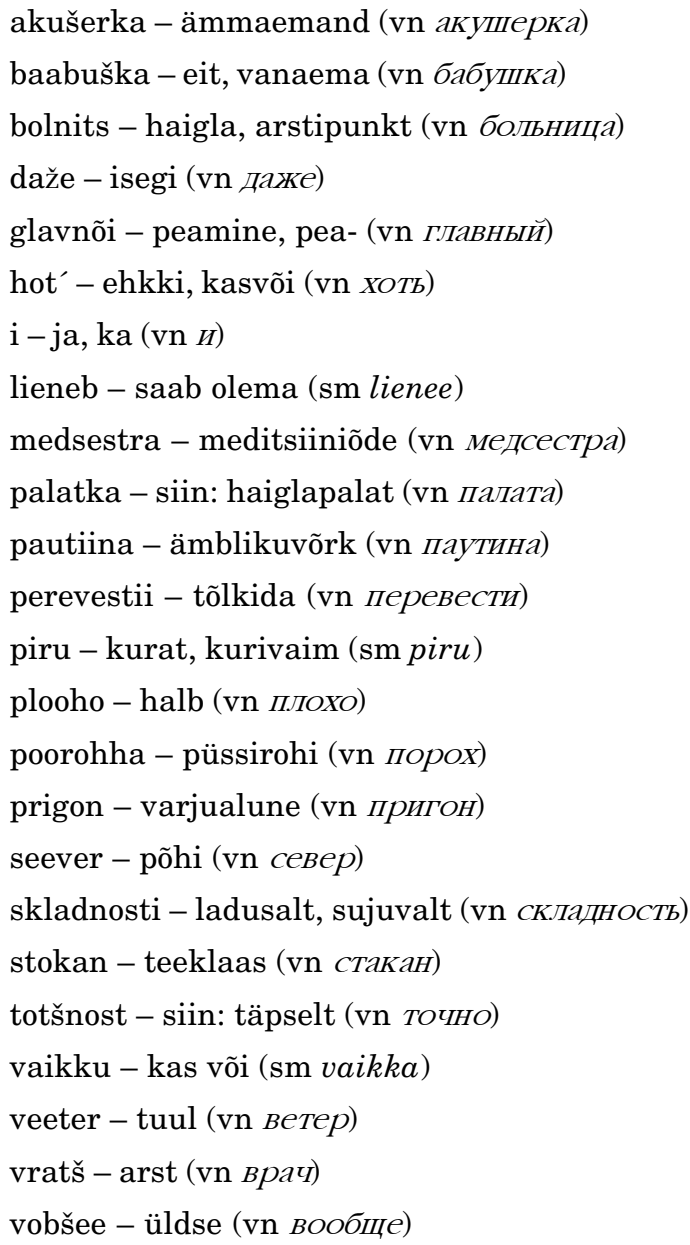




\section{Kommentaarid}

1 Eesti-vene segakeel, ligikaudne tõlge: Samuti kui haiglaravimid, kõik korkidega suletud, nii on seegi, et õhk ligi ei pääseks. Pimedas kohas hoida, rohud on kõik, valguse käes ju ei hoia neid.

2 Pärast vaimulike represseerimist 1920.-1930. aastatel läks Siberi eesti külades ja mitmel pool mujalgi kiriklike talitluste läbiviimine vanemate naiste kätte.

3 Enamasti malaaria, vahel ka muu "palavikuhaigus".

4 Ligikaudne tõlge Gunars Tisonsilt: Meie Issand Jeesus Kristus sõidab üle mere. Üheksa roosi käes. Kolm sinist, kolm valget ja kolm punast. Sinine hääbus, valge valgus, punane ära kuivas. Puhu roosi välja nagu vana kuu, nagu puust [arusaamatu sõna] mädaneb, Māra [Maarja] nimest aamen, Māra nimest aamen, Māra nimest aamen.

5 Ligikaudne tõlge Gunars Tisonsilt: Jeesus seisab Kolgata mäel, hõõrub kolme roosi. Ühe sinise, ühe punase, ühe musta. Hõõrub maha roosi. Meie Isa taevas, pühitsetud olgu sinu nimi. Tulgu sinu riik igavesti. Aamen.

\section{Arhiiviallikad}

SKSÄ = Suomalaisen Kirjallisuuden Seuran kansanrunousarkiston äänitearkisto

ERA, CD = Eesti Kirjandusmuuseum, Eesti Rahvaluule Arhiivi heliarhiiv, digitaalsalvestused CD-del

EFA = Eesti Kirjandusmuuseum, Eesti folklooriarhiivi rahvaluulekogu (Eesti Rahvaluule Arhiivi kogu alates 1996. aastast)

RKM = Riikliku Kirjandusmuuseumi (nüüd Eesti Kirjandusmuuseumi) rahvaluulekogu

\section{Kirjandus}

Alver, Bente G. \& Selberg, Torunn 1989. Alternative Medicine in Today's Society. Kvideland Reimund \& Sehmsdorf, Henning K. \& Simpson, Elizabeth (toim). Nordic Folklore: Recent Studies. Folklore studies in translation. Bloomington: Indiana University Press, lk 207-220.

EE 1990 = Eesti Entsüklopeedia 5. Tallinn: Valgus.

Eisen, Matthias Johann 1919. Eesti mütoloogia. Tartu: Eestimaa Kooliõpetajate Vastastiku Abiandmise Seltsi raamatukauplus.

Foucault, Michel 2003. Hullus ja arutus: Hullumeelsuse ajalugu klassikalisel ajastul. Tartu: Ilmamaa.

Granö, Paavo 1999 [1915]. Siperian suomalaiset. Kajanto, Anneli (toim). Namsarai ja muita matkaesseitä Kansanvalistusseuran kalentereista autonomian ajalta. Helsinki: Suomalaisen Kirjallisuuden Seura, lk 122-133. 
Anu Korb

Honko, Lauri 1960. Varhaiskantaiset taudinselitykset ja parantamisnäytelmä. Hautala, Jouko (toim). Jumin keko: Tutkielmia kansanrunoustieteen alalta. Tietolipas 17. Helsinki: Suomalaisen Kirjallisuuden Seura, lk 43-111.

Honko, Lauri 1982. Folk medicine and health care systems. ARV: Nordic Yearbook of Folklore 38. Uppsala: The Royal Gustavus Adolphus Academy, lk 57-85.

Kleinman, Arthur 1980. Patients and healers in the context of culture: An exploration of the boderland between anthropology, medicine and psychiatry. Comparative studies of health systems and medical care 3. Berkeley: University of Californian Press.

Korb, Anu (koost) 1996. Ei oska rääkimise moodi kõnelda: Zolotaja Niva, Semjonovka, Jurjevka, Koidula. Eesti asundused 2. Tartu: Eesti Kirjandusmuuseum.

Korb, Anu (koost) 1998. Seitse küla Siberis. Eesti asundused 3. Tartu: Eesti Kirjandusmuuseum.

Kõiva, Mare 1992. Loitsud ja rahvaarstid. Rüütel, Ingrid (koost \& toim). Ida-Virumaa rahvakultuurist. Tallinn: Infotrükk, lk 117-131.

Kõiva, Mare 1995. Loitsust riituseni. Hiiemäe, Mall \& Kõiva,Mare (toim). Rahvausund tänapäeval. Tartu: Eesti Ta Eesti Keele Instituut, lk 175-194.

Kõiva, Mare 1998. Palindroomidest, aga ennekõike tähtvormelitest. Kalda, Mare \& Kõiva, Mare (toim). Sator 1: Artikleid usundi- ja kombeloost. Tartu: Eesti Keele Instituut, lk 190-213.

Kõiva, Mare 1999. Numeraalid. Ühest loitsude alaliigist. Leete, Art (toim). Eesti Rahva Muuseumi aastaraamat 43. Tartu: Eesti Rahva Muuseum, lk 115-132.

Kõivupuu, Marju 2000. Rahvaarstid Võrumaalt: Noor ja vana Suri Hargla kihelkonnast. Võru: Võro Instituut.

Laugaste, Eduard 1936. Nõia ja nõiduse nimetusi eesti murdeis. Eesti Kirjandus 11, lk 515-526 \& 12, lk 558-572.

Loorits, Oskar 1928. Liivi rahva usund: Mit einem Referat: Der Volksglaube der Liven III. Acta et Commentationes Universitatis Tartuensis (Dorpatensis) = Tartu Ülikooli toimetused B (Humaniora) 16: 1. Tartu.

Loorits, Oskar 1990. Eesti rahvausundi maailmavaade. Tallinn: Perioodika.

Lönnrot, Elias 1981 [1839]. Suomalaisen Talopojan kotilääkäri. Tampere: Wirtanen.

Manninen, Ilmari 1925. Üldjooni meie rahvameditsiinist. Eesti Kirjandus 11, lk 453459.

Mansikka, Viljo Johannes 1929. Lithauische Zaubersprüche. Folklore Fellows Communicationes 87. Helsinki. Helsinki: Suomalainen tiedeakatemia.

Mathisen, Stein R. 1989. Faith Healing and Concepts of Illness: An Example from Northern Norway. Temenos 25, lk 41-68.

Paju, Aili 1989. Muistsetest rahvaarstidest teadlase pilgu läbi. Kleio 2, lk 81-82.

Perepis 1905 = Первая всеобщая перепись населения Российской империи: 1897. г. 4. Санкт-Петербург. 
Põvvat, Lea 1992. Teaduslik meditsiin contra rahvameditsiin: Pilk ajalukku. Kultuur ja Elu 12, lk 46-51.

Rooks, Gerhard 1929. Ebaarstimine Eestis. Eesti Arst 10, lk 377-382.

Rørbye, Birgitte 2003. Rahvameditsiinist meditsiinifolkloristikani. Mäetagused: Hüperajakiri 22, lk 7-19 (http://haldjas7.folklore.ee/tagused/nr22/birg.pdf - 12. september 2006).

Saari, Juha 1994. Valoa Siperiaan: Kirkollinen työ Siperian suomalasten parissa 18631921. Helsinki: Helsingin Yliopisto.

SKVR 1908-1948 = Suomen kansan vanhat runot 1-15. Suomalaisen Kirjallisuuden Seuran toimituksia. Helsinki: Suomalaisen Kirjallisuuden Seura.

Sulkala, Helena 2002. Põhjaperifeeria kveenid. Jüri Viikberg (koost \& toim). Krimmi kogumik [I]: konverentsi "140 aastat eestlust Krimmis" ettekanded (09.-10.09.2001, [Beregove, Ukraina]) = Крымский сборник: доклады конференции - 140 лет эстонства в Крыму (09.-10.09.2001, [Берегове, Украина]). Tallinn: Eesti Keele Sihtasutus, lk 216230.

Templing = Темплинг, Владимир Я. 2005. Сельские врачеватели в сибирском социуме. Карабулатова, Ирина C. (koost \& toim). Живая традиция заговора Сибири: Сакрально-ритуальный дискурс знахарской практики (коллективная монография). Тюмень: Экспресс, lk 213-299.

Tuovinen, Jane 1984. Tietäjistä kuppareihin: Kansanparannuksesta ja parantajista Suomessa. Porvoo: Söderström.

Valk, Ülo 1998. Ristimise tähendusest eestlastele rahvausundi andmetel. Kalda, Mare \& Kõiva, Mare (toim). Sator 1: Artikleid usundi- ja kombeloost. Tartu: Eesti Keele Instituut, lk 137-156.

Vallikivi, Laur 2005. Arktika nomaadid šamanismi ja kristluse vahel: Jamb-to neenetsite pöördumine baptismi. Studia Ethnologica et Folkloristica Tartuensia 8. Tartu: Tartu Ülikooli Kirjastus.

Veidemann, Andra 1985. Rahvapärased arusaamad roosihaigusest ja selle ravimisest Eestis 19. sajandil ja 20. sajandi algul. Ants Viires (toim). Eesti külaelu arengujooni. Tallinn: Eesti NSV Teaduste Akadeemia, lk 130-152.

Viikberg, Jüri \& Vaba, Lembit 1984. Siberi põhjaeestlasi kõnetamas. Keel ja kirjandus 4 , lk 210-223. 


\title{
Summary
}

\section{Healing Skills as Collective Lore Knowledge: Ryzhkovo Village in Siberia}

\author{
Anu Korb
}

Key words: community, multiculturalism, folk medicine, healing spell, healer, Siberia

The article explores the use of folk healing methods in the mixed Estonian and Finnish lore group (called virulased), who have settled in the village of Ryzhkovo. The village was established around 1803 as an ethnically mixed Lutheran settlement in West Siberia. The material is based on fieldwork conducted by the author in the village in 1999, 2000 and 2004. By this time, Ryzhkovo had become a multiethnic and multilingual village, where the territory was divided in half between the local Latvian population and the virulased.

Knowledge about popular healing methods and healing words has been better preserved in older Siberian villages than in Estonia. In Siberia it was necessitated by both a practical need as well as living in the sphere of influence of the neighbouring cultures, where verbal magic was well preserved. Folk healers, however, do not emerge very prominently among the virulased lore group in Ryzhkovo, since healing skills are viewed as a collective traditional knowledge passed on from one generation to another. It is believed that healing skills and spells are accessible to and can be learned by anyone. The multiethnic and multilingual environment has favoured the adoption and incorporation of healing spells and methods of the neighbouring cultures in the local tradition; folk healing methods have also been upheld owing to pragmatic reasons. Factors affecting the fading of the tradition include the long-term socio-political pressure on folk healers, forceful development of the national medical system, as well as the attitudes of members of the lore group, who traditionally accepted only healers of advanced age. The changes have affected the adaptation of healing methods, types of spells, and narrowing of repertoire. At the same time, in the contemporary situation of political and economic freedom, interest towards popular healing ways and methods is definitely growing. 